\title{
Induction of drought tolerance by inoculation of Bacillus aryabhattai on sugarcane seedlings
}

\section{Indução de tolerância à seca em mudas de cana-de-açúcar com a inoculação de Bacillus aryabhattai}

\author{
André MAY ${ }^{1}$; Bruno Rafael Almeida MOREIRA ${ }^{2}$; Gabriel Moura MASCARIN ${ }^{3}$; Ronaldo Silva VIANA ${ }^{4}$ \\ Michelli Souza SANTOS ${ }^{5}$; Evandro Henrique Figueiredo Moura SILVA ${ }^{6}$; Nilza Patrícia RAMOS ${ }^{7}$ \\ Itamar Soares de MELO ${ }^{8}$ \\ ${ }^{1}$ Researcher, Embrapa Meio Ambiente, SP 340, km 127,5, Bairro Tanquinho Velho, CEP: 13918-110, \\ Jaguariúna, SP, Brasil. email: andre.may@embrapa.br \\ ${ }^{2}$ Student, Faculdades de Ciências Agrárias e Tecnológicas, UNESP, Dracena/SP, email: \\ bruno_rafael.m05@hotmail.com \\ ${ }^{3}$ Researcher, Embrapa Meio Ambiente, Jaguariuna, SP, Brasil. email: gabriel.mascarin@embrapa.br \\ ${ }^{4}$ Researcher, Faculdades de Ciências Agrárias e Tecnológicas, UNESP, Dracena/SP, email: \\ ronaldo@dracena.unesp.br \\ ${ }^{5}$ Student, CAPES, Embrapa Meio Ambiente, Jaguariuna, SP, Brasil. email: michellisantos30@hotmail.com \\ ${ }^{6}$ Student, ESALQ/USP, Piracicaba, SP, Brasil. email: ehfmsilva@gmail.com \\ ${ }^{7}$ Researcher, Embrapa Meio Ambiente, Jaguariuna, SP, Brasil. email: nilza.ramos@embrapa.br \\ ${ }^{8}$ Researcher, Embrapa Meio Ambiente, Jaguariuna, SP, Brasil. email: itamar.melo@embrapa.br
}

Recebido em: 27-03-2019; Aceito em: 12-07-2019

\begin{abstract}
In twenty-first century, free-living endophytic and rhizosphere-competent microbes have become breakthrough strategies to meet global demands for sustainable foods and renewable fuelstocks owing to their great potential to produce stress-tolerant food and energy crops. Here, we investigate how Bacillus aryabhattai could mitigate water stress by drought in sugarcane seedlings. Briefly, the sugarcane genotypes, namely IAC91-1099 and RB85-5156,

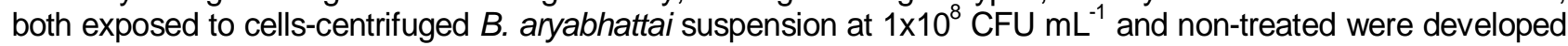
under irrigation regimes of $0,7,14$ and 21 days to simulate different degrees of soil moisture content. The osmotolerant bacterium remarkably enhanced development of aboveground structures and root system, mainly in irrigated seedlings of IAC91-1099. Clearly noted that microbial metabolism depends on genotype and soil water potential to promote plant growth. This bacterium probably enabled sugarcane plants in early phenological stages to cope with water deficit by regulation of plant growth hormones along with solubilization of nutrients. Of particular importance, the bacterium exerted more pronounced effects by conferring drought tolerance at 7 and 14 days irrigation interval, irrespective of sugarcane genotype, which also translated into increased biomass of shoots and roots. Microbial degradation of ethylene precursors exuded in rhizosphere could reasonably explain why $B$. aryabhattai-associated seedlings developed deeper root systems to uptake water and nutrients and, consequently, allocating larger amounts of dry matter to shoots. Collectively, our findings provide relevant insights on the beneficial effects of the cacti-associated $B$. aryabhattai in alleviating the harmful effects of drought stress in seedlings and contribute to increasing our understanding of the phenotypic outcomes from the interaction between sugarcane genotypes and a beneficial rhizobacterium. Hence, this bacterial inoculant forms a low-cost and ecologically sound strategy to enhancing drought stress tolerance in sugarcane crops planted in water-limited zones in Brazil.
\end{abstract}

Additional keywords: morphological change; plant growth-promoting bacterium; rhizobacterium; Saccharum spp.; water stress.

\section{Resumo}

No século XXI, os microrganismos endofíticos e rizosféricos de vida livre tornaram-se estratégias inovadoras para atender às demandas globais por alimentos sustentáveis e por combustíveis renováveis, devido ao seu grande potencial em promover culturas alimentares e energéticas tolerantes a estresses. Nessa pesquisa, investigou-se como o Bacillus aryabhattai pode mitigar a deficiência hídrica em mudas de cana-de-açúcar. Os genótipos de cana-de-açúcar, IAC91-1099 e RB85-5156, ambos expostos ou não a uma suspensão de $B$. aryabhattai centrifugada, $1 \times 108 \mathrm{UFC} \mathrm{mL}^{-1}$, foram cultivados sob regimes de irrigação de $0 ; 7 ; 14$ e 21 dias para simular diferentes graus de umidade do solo. A bactéria osmotolerante melhorou notavelmente 0 desenvolvimento de estruturas aéreas e do sistema radicular, principalmente em mudas irrigadas de IAC91- 
1099. A bactéria B. aryabhattai, provavelmente, permitiu que as plantas de cana, em fases fenológicas precoces, minimizassem as consequências da deficiência hídrica mediante regulação de fito-hormônios e solubilização de nutrientes. De particular importância, a bactéria exerceu efeitos mais pronunciados ao conferir tolerância à seca em 7 e 14 dias de intervalo de irrigação, independentemente do genótipo da cana-de-açúcar, o que também se traduziu no aumento da biomassa da parte aérea e das raízes. A degradação microbiana dos precursores de etileno presentes na rizosfera poderia explicar, razoavelmente, por que as plântulas associadas a $B$. aryabhattai desenvolveram sistemas radiculares mais profundos para absorver água e nutrientes e, conseqüentemente, alocar maiores quantidades de matéria seca na parte aérea. Esses resultados fornecem informações relevantes sobre os efeitos benéficos de $B$. aryabhattai no alívio dos efeitos prejudiciais do déficit hídrico em plântulas e contribuem para aumentar nossa compreensão dos resultados fenotípicos da interação de genótipos de cana-deaçúcar com uma rizobactéria benéfica. Portanto, esse inoculante bacteriano forma uma estratégia ecologicamente correta e de baixo custo para mitigar a tolerância à deficiência hídrica em áreas de cana-deaçúcar plantadas em terras secas.

Palavras-chave adicionais: alterações morfológicas; bactéria promotora de crescimento vegetal; deficiência hídrica; rizobactéria; Saccharum spp.

\section{Introduction}

Brazil is the world's largest producer of sugarcane (Saccharum spp.) and an exporter of industrialized sugar. For the production of bioethanol, it is only surpassed by the United States, whose industrial biofuel production uses corn (Zea mays L.) as the source of starchy grains. The bulletin about the Brazilian sugarcane harvest, planned and issued regularly by the National Food Supply Company (CONAB), linked to the Brazilian Ministry of Agriculture, Livestock, and Food Supply (MAPA), projects that in 2018/19, the planted area will exceed 10 million hectares, which will produce 35.5 million tons of sucrose, 28 million liters of hydrated alcohol, and 11 million liters of anhydrous alcohol (Mapa, 2017; Conab, 2018).

Nationally, the average replanting rate of sugarcane is equivalent to $10 \%$. Particularly in sugarcane plants, the pre-sprouted seedling (PSS) technique is used to revitalize unproductive fields and establish of secondary nurseries. Although technically efficient, this propagation method is unlikely to be sensitive to water deficit; in planting, there will be intense dehydration of PSS, if the availability of water in the soil is not sufficient to the meet evapotranspiration demand of the crop. The main consequences are undoubtedly: generalized mortality, unsatisfactory productive yield of high-quality raw material, and inevitably unsustainable cost of production (Agroanalysis, 2017; Endres et al., 2018).

Agricultural productivity is unidirectionally influenced by multiple biotic and abiotic factors, mostly due to water deficit (Naser and Shani, 2016). Scientific research with emphasis on drought tolerance induced by application of Bacillus aryabhattai (Firmicutes: Bacillaceae), a plant growth inducing species, in soybean (Glycine max L. Merril) and rapeseed (Brassica napus $\mathrm{L}$.) proved the possibility to biologically mitigate tolerance (Siddikee, 2010; Park et al., 2017). In addition, experimental trials conducted in both the field and greenhouse found, in addition to drought tolerance, significant productive returns for sugarcane and corn treated with Bacillus spp. and Azospirillum spp., re- spectively (Kavamura et al., 2013; Santos et al., 2017).

Plant growth-promoting microorganisms are authentically effective in the production of drought tolerant crops. In rhizosphere, or endophytically, these plants are able to withstand possible water deficits by the synthesis of siderophores; organic complexes of heavy metals, mainly Fe; and secretion of gibberellins, abscisic acid, cytokinins and indole-acetic acid. These phytohormones alter the architecture of the root system, morphoanatomically, by promoting the absorbent and adjacent roots; consequently, intensifying the absorption of mineral resources that condition plant growth and development. The other notable direct and indirect benefits include solubilization of nitrates, phosphates, $\mathrm{Ca}, \mathrm{Mg}, \mathrm{Zn}$, and $\mathrm{Si}$, making them readily assimilable for functional roots; biofixation of atmospheric $\mathrm{N}_{2}$; symbiotic association to arbuscular mycorrhizal fungi, which is very important to the interception of $\mathrm{P}$, a mineral element practically immobile in soil solution; stimulation of the biosynthesis of jasmonic and salicylic acids, which are fundamental to the phytohormonal signaling of precursor routes of secondary metabolites for the synthesis of antimicrobial compounds, including alkaloids, aldehydes, phenols and phytoalexins, and antioxidant enzymes that are sequesters of reactive oxygen species; and biocontrol of potential phytopathogens by the synthesis of antibiotics and interspecific competition for rhizosphere niches and substrates vital to microbial metabolism (Schmidt et al., 2014; Cherif et al., 2015; Mareque et al., 2015).

Because sugarcane is extensively planted in water-limited zones in Brazil where crop yield is strikingly stagnant, one appealing and environmentally friendly approach lies in exploring the ability of the cacti-rhizobacterium $B$. aryabhattai to ameliorate plant growth under drought stress when applied as a bioinoculant on sugarcane seedlings. Therefore, the main goal in this study was to assess the effectiveness of this osmotolerant rhizobacterium in promoting sugarcane growth and enhancing the drought stress tolerance as to provide the foundation for the development of the first bioinoculant applied to sugarcane seedlings that sustain its production in Brazilian regions that suffer from water scarcity. 


\section{Materials and methods}

\section{Location and experimental design}

The experiments were set up and conducted at the Brazilian Agricultural Research Corporation (Embrapa Environment), located in Jaguariúna, a municipality of the State of São Paulo, Brazil. Between January and March 2018, sugarcane plant varieties IAC91-1099 and RB85-5156 were grown in a greenhouse. A completely randomized design was used, with eight replications, in a $2 \times 2 \times 4$ factorial scheme, respectively: sugarcane variety (IAC91-1099 and RB85-5156), seedling type (natural: not inoculated, and treated: inoculated with Bacillus aryabhattai), and irrigation frequency $(0,7,14$, and 21 days).

\section{Acquisition and cultivation of $B$. aryabhattai}

The osmotolerant bacterium, B. aryabhattai, was isolated from a Brazilian semi-arid cactaceous species (Kavamura et al., 2013). After completing the genotypic characterization, strain CMA 1363 was added to the collection of microorganisms at the Laboratory of Environmental Microbiology (LMA) of Embrapa Environment. For the experimental assays, the strain was cultivated in Petri dishes, maintained in a biochemical oxygen demand (BOD) growth chamber at $25^{\circ} \mathrm{C}$ for $24 \mathrm{~h}$. Bacterial colonies, after grown on solidified yeast extract medium, were then transferred to similarly formulated liquid medium. The bacterial liquid culture was shaken in rotary incubator shaker at $25^{\circ} \mathrm{C}$ for $72 \mathrm{~h}$. The bacterial broth was centrifuged at $7000 \mathrm{rpm}$ for $15 \mathrm{~min}$. Finally, in a spectrophotometer, the bacterial cell concentration was adjusted to $1 \times 10^{8}$ CFU mL ${ }^{-1}$ (Santos et al., 2017).

\section{Formation and biological treatment of seedings}

Seedlings were formed by adopting the technique of multiplication of mini-wheels, detailed by Landell et al. (2012). Individually planted in tubes, filled with bark of carbonized Pinus sp..

At the stage of formation, completed in forty days, seedlings were treated with the bacterial suspension immediately before planting them to the final location.

\section{Substrate preparation and transplanting}

At transplanting, planting boxes (1.0 m length $\times$ $0.6 \mathrm{~m}$ width $\times 0.6 \mathrm{~m}$ height) were filled with gravel, $0.2 \mathrm{~m}$ layer at the bottom of the boxes, artificial origin aggregate with excellent drainage properties, and sieved soil, from a dystrophic Red-Yellow Latosol as a substrate. During the substrate preparation, the composite soil sample was characterized at points collected in an area adjacent to the greenhouse (Table 1).

Table 1 - Physical and chemical properties of the dystrophic Red-Yellow Latosol.

\begin{tabular}{ccccccc}
\hline \multicolumn{7}{c}{ Attribute } \\
\hline $\mathrm{pH}$ & $\begin{array}{c}\mathrm{P}-\mathrm{mehlich} \\
\left(\mathrm{mg} \mathrm{dm}^{-3}\right)\end{array}$ & $\begin{array}{c}\mathrm{K}^{+} \\
\left(\mathrm{mmol}_{\mathrm{C}} \mathrm{dm}^{-3}\right)\end{array}$ & $\begin{array}{c}\mathrm{Ca}^{2+} \\
\left(\mathrm{mmol}_{\mathrm{c}} \mathrm{dm}^{-3}\right)\end{array}$ & $\begin{array}{c}\mathrm{Mg}^{2+} \\
\left(\mathrm{mmol}_{\mathrm{c}} \mathrm{dm}^{-3}\right)\end{array}$ & $\begin{array}{c}\text { Org. Mat. } \\
\left(\mathrm{g} \mathrm{kg}^{-1}\right)\end{array}$ & $\begin{array}{c}\text { Clay } \\
\left(\mathrm{g} \mathrm{kg}^{-1}\right)\end{array}$ \\
\hline 5.1 & 24.2 & 3.6 & 45.6 & 22.8 & 38.6 & 77.0 \\
\hline
\end{tabular}

The plant growth substrate was mixed with the aid of a concrete mixer, 4 months before the experiment, to neutralize reactions of potential acidity in the soil. The fertilization in the planting boxes consisted in the application of doses equivalent to $40 \mathrm{~N}, 150 \mathrm{P}_{2} \mathrm{O}_{5}$, and $140 \mathrm{~kg} \mathrm{ha}^{-1} \mathrm{~K}_{2} \mathrm{O}$, in the form of Urea, Simple Superphosphate, and Sodium Chloride, respectively, evenly distributed at $10 \mathrm{~cm}$ below the upper surface of the boxes, in the bottom of furrows, during the filling with sifted and limed earth, to simulate the local fertilization of sugarcane plans.

\section{Management of water stress environments}

To determine the field capacity of the soil used, water was applied to the soil, reserved in a $2 \mathrm{~m}$ width dam, until it reached the state of water saturation. After the soaking, the system was covered, superficially, with plastic canvas, avoiding water loss through evaporation. The humidity was monitored at regular intervals of $12 \mathrm{~h}$, until insignificant variation in the drainage profile was observed. In the laboratory, undisturbed soil samples, collected by volumetric ring, were dehydrated in a forced air circulation oven at $105^{\circ} \mathrm{C}$ for $48 \mathrm{~h}$. The field capacity was then calculated by mass difference.

At irrigation dates, sufficient volumes of water were applied to reestablish field capacity, dynamically monitored by the CS 616 sensor from Campbell Scientific.

\section{Technical evaluation of induced drought tolerance}

The technical evaluation, carried out 60 days after transplanting, considered the vegetative characteristics, plant height, number of tillers and leaves, stem diameter, dry mass of roots and shoots as biologically induced morphological indicators of tolerance to drought. The plant height was measured by a ruler graduated in centimeters; the number of tillers and leaves were counted, disregarding of vestigial and underdeveloped structures; the stem diameter was measured with digital caliper, in three regions: lower, middle and higher. To determine the dry mass of roots and shoots (samples composed of stems, tillers and leaves) they were washed with tap water to remove soil and impurities and then dehydrated in a forced air circulation oven at $60^{\circ} \mathrm{C}$, until they reached constant masses.

\section{Data analysis}

The Shapiro-Wilk normality test was applied to all data sets separated by each response variable measured at the end of the experiments. After the Gaussian distribution was tested, the data were submitted to regression analysis. To the fitted models, the analysis of variance was applied to test for robustness 
together with the coefficient of determination (adjusted $R^{2}$ ) and $P$-value at the level of $5 \%$ significance. In the exploratory analysis of morphological changes induced by the application of $B$. aryabhattai in sugarcane plants under water stress, we applied main component analysis and fuzzy c-means algorithm, classifier and unsupervised pattern identifier that, distinct from the kmeans grouping method, based on Boolean or binary logic, allows the object or individual to have real values between 0 and 1 (Nayak et al., 2015). The number of components necessary for orthogonal reduction of the dimensionality of the original data set was determined, preserving the maximum variability statistically, possibly interpreted in subsets free of related variables, by the Kaiser-Meyer-Olkin test, which considers useful only eigenvalue unit or higher (Jolliffe \& Cadima, 2016). Additionally, we determined: normalized contribution of vegetative characteristic for the variant of principal and representative Cartesian component of environment of induced water stress. Once the factorial map was developed, the fuzzy c-means algorithm was applied to the clustering of microclimates by similarity, calculated by the Euclidean metric. Multivariate statistical analyses were performed in $\mathrm{R}$ environment ( $\mathrm{R}$ Core Team, 2017).

\section{Results}

Effects of genotype, frequency of irrigation, and $B$. aryabhattai on characteristics in morphological traits

The genotype influenced plant height, number of tillers and leaves, dry mass of roots and shoot, suggesting that these sugarcane cultivars grow and develop differently. On the other hand, the varieties IAC91-1099 and RB85-5156, under induced water stress, developed shoots that were morphologically similar in relation to the diameter (Table 2).

Table 2 - Analysis of variance genotype effects, irrigation frequency, and biological treatment on vegetative characteristics of sugarcane plant varieties, IAC91-1099 and RB85-5156, grown in environments of induced water stress.

\begin{tabular}{|c|c|c|c|c|c|c|}
\hline \multirow{2}{*}{ Source of variation } & \multicolumn{6}{|c|}{ Vegetative Characteristic $^{(1)}$} \\
\hline & $\mathrm{H}$ & NT & $\mathrm{NL}$ & SD & RDM & SDM \\
\hline & \multicolumn{6}{|c|}{$F_{\text {calculated }}$} \\
\hline Genotype (A) & $208.37^{*}$ & $30.72^{*}$ & $219.22^{*}$ & 3.86 & $721.11^{*}$ & $249.13^{*}$ \\
\hline Frequency (B) & $185.35^{\star}$ & $7.46^{*}$ & $61.81^{*}$ & $105.03^{*}$ & $107.71^{*}$ & $136.86^{*}$ \\
\hline Biological treatment (C) & $6.41^{*}$ & $11.54^{*}$ & $19.24^{*}$ & $21.06^{*}$ & $222.24^{*}$ & $42.50^{*}$ \\
\hline$A \times B$ & $49.74^{*}$ & 1.43 & $9.63^{*}$ & $33.06^{*}$ & $39.50^{*}$ & $23.62^{*}$ \\
\hline$A \times C$ & $19.29^{*}$ & $10.74^{*}$ & 1.64 & $5.62^{*}$ & $190.11^{*}$ & 3.68 \\
\hline$B \times C$ & 2.60 & 1.46 & $3.72^{*}$ & 3.56 & $11.46^{*}$ & $8.18^{*}$ \\
\hline$A \times B \times C$ & $2.99^{*}$ & 0.65 & $4.73^{*}$ & $4.23^{*}$ & $10.78^{*}$ & $5.27^{*}$ \\
\hline Coefficient of variation (\%) & 7.93 & 52.14 & 17.54 & 12.20 & 25.07 & 8.02 \\
\hline$P$-value & $0.20^{*}$ & $0.45^{*}$ & $0.81^{*}$ & $0.49^{*}$ & $0.66^{\star}$ & $0.23^{*}$ \\
\hline
\end{tabular}

(1) $\mathrm{H}$ - Plant height; NT - number of tillers; NL - number of leaves; ST - stem diameter; RDM - root dry mass; SDM - shoot dry mass. * Significant by the Shapiro-Wilk and Fisher tests $(P<0.05)$.

There was interaction of irrigation frequency and biological treatment only for number of leaves, dry mass of roots and shoot. Therefore, the range of water stress and biological performance of $B$. aryabhattai cells are independent factors for plant height, number of tillers, and stem diameter.

\section{Interactive effect of irrigation frequency and biological treatment in phenotypic characteristics}

The interactive effect of irrigation frequency and biological treatment on plant height, number of tillers and leaves, stem diameter, dry mass of roots and shoot of the sugarcane varieties, IAC91-1099 and RB85-5156, natural and treated, cultivated in environments of induced water stress, is presented in Figure 1.

\section{Plant height and number of tillers}

The natural and treated plants of variety IAC91-1099 grew to sizes equivalent to 40.6 and
$41.5 \mathrm{~cm}$, respectively. Therefore, plant height is fundamental, independence of the such factors, as frequency of irrigation and biological treatment.

The models adjusted to the vegetative characteristic in question suggest the possibility of plants at 60 days - natural and treated - of larger size, if they are irrigated at intervals of 7 and 14 days. Shifts longer than these, in addition to limiting sugarcane growth, probably damaging physiological routes and biochemical reactions by the prolonged water stress, in addition to compromising the biological performance of $B$. aryabhattai cells. Therefore, plants treated with the bacterium and irrigated at a frequency of 7 days grew, on average, $45.18 \mathrm{~cm}$, while uninoculated plants managed at the frequency of 7 days were $43.7 \mathrm{~cm}$.

For the variety RB85-5156, larger irrigation intervals (21 days) favored the plant growth of both natural and treated plants, whose sizes were 34.7 and $38.2 \mathrm{~cm}$, respectively. 

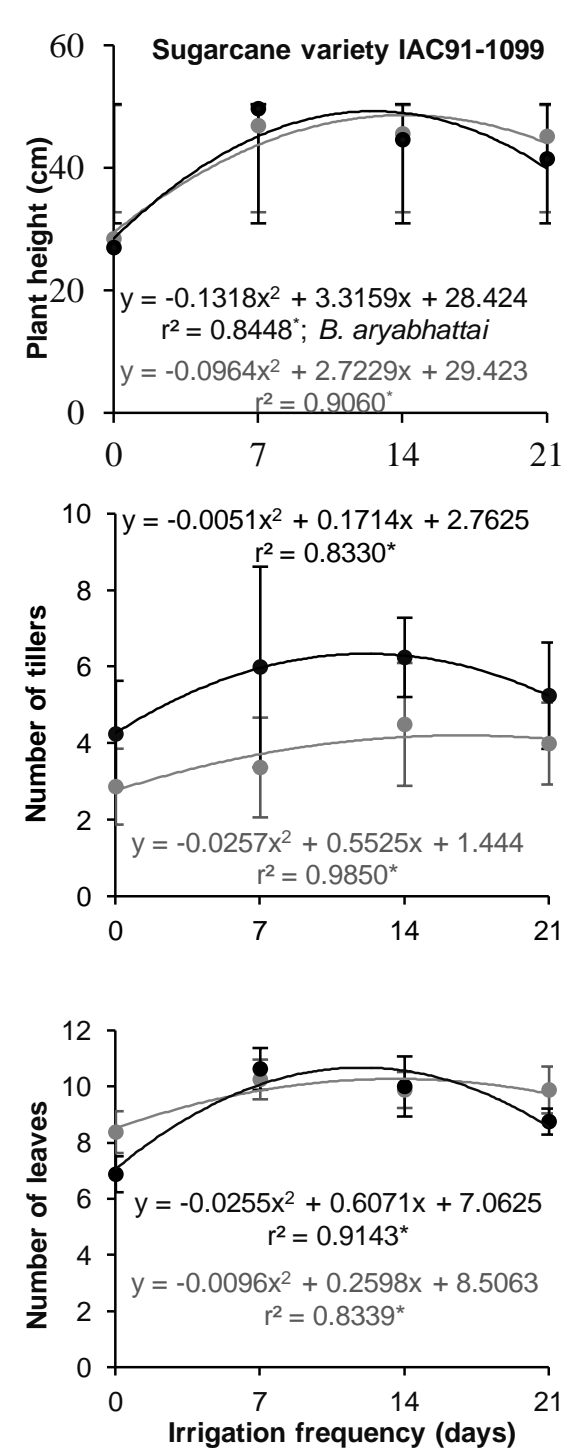
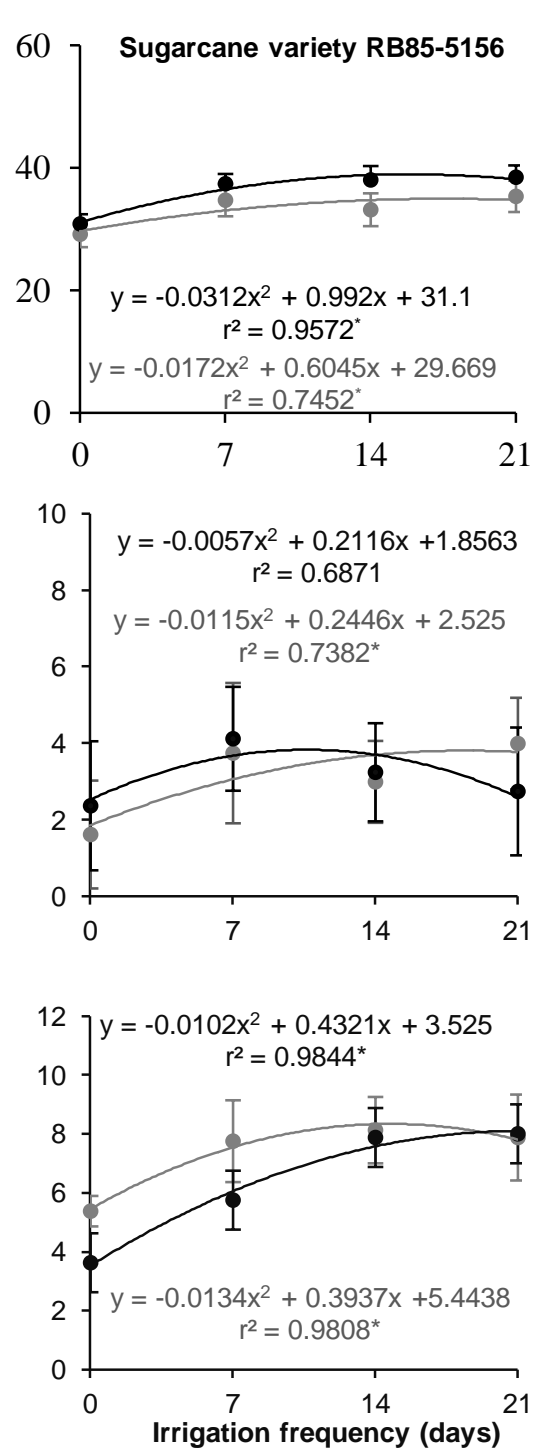
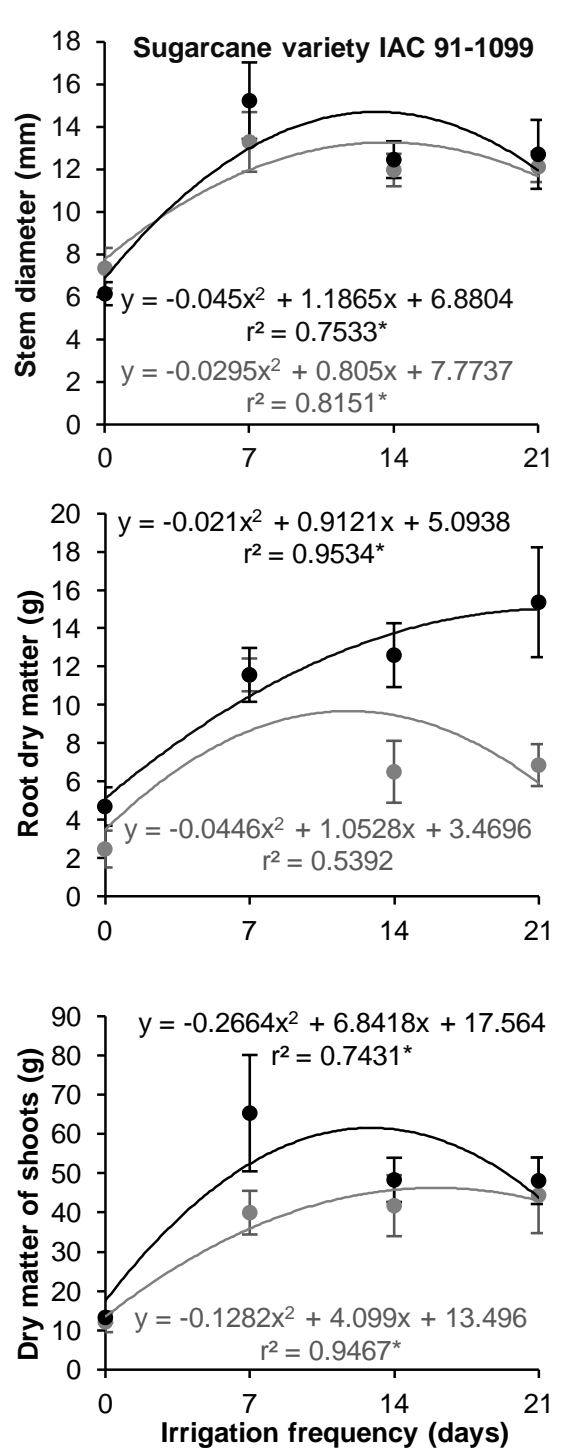
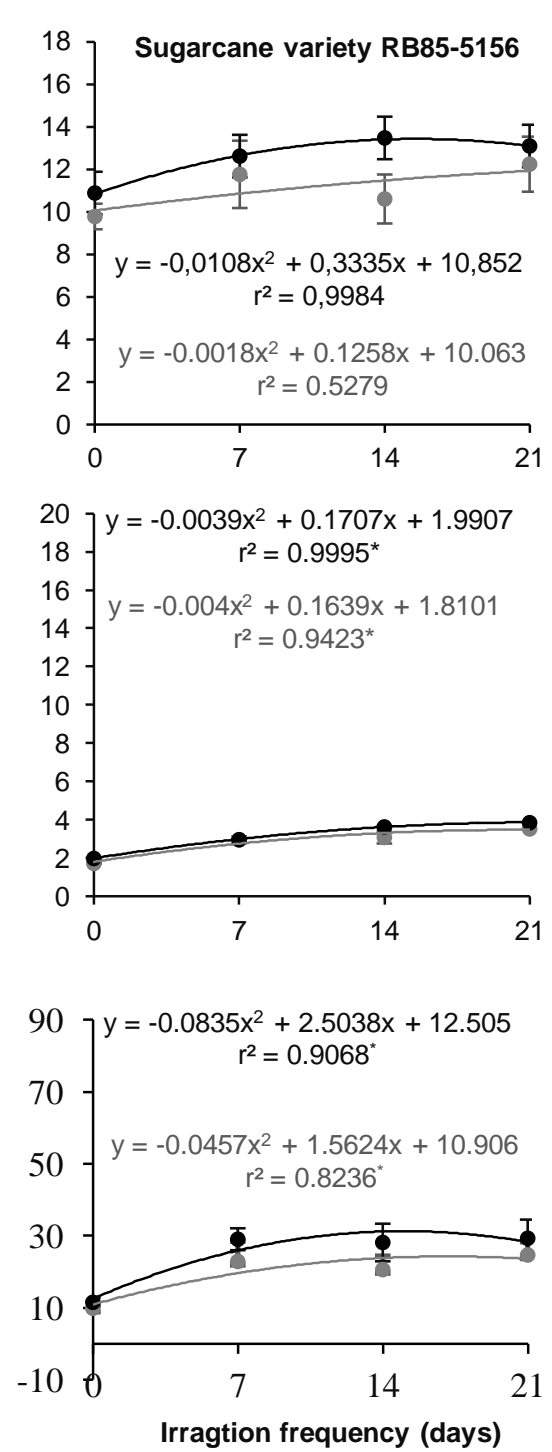

Figure 1 - Interactive effect of irrigation frequency and biological treatment on vegetative characteristics of the sugarcane plant varieties, IAC91-1099 and RB85-5156, natural and treated with $B$. aryabhattai, cultivated in environments of induced water stress; * Significant by Fisher's test $(P<0.05)$. 


\section{Number of leaves}

The performance of $B$. aryabhattai, in relation to the growth promotion in sugarcane cultivation, is conditioned to the availability of water in cultivation substrate for the cultivar IAC91-1099. Therefore, this assumption justifies the greater number of leaves counted in treated plants, irrigated at intervals of 7 and 14 days, of 10 and 10.6 leaves, respectively, compared to those submitted to the 21-day shift, which produced only 8.6 leaf units. For the variety RB85-5156, the natural and treated plants irrigated at intervals of 7 and 14 days yielded 7.5 and 6 , and 8.3 and 7.6 leaves, respectively. Therefore, in addition to being genetically defined and controlled, the production of leaves on sugarcane plant varieties, IAC91-1099 and RB855156 , is affected by the water restriction interval and by the presence of the biological asset.

\section{Stem diameter}

Cultivated under irrigation intervals of 7 and 14 days, plants of IAC91-1099 and RB85-5156 inoculated with the bacteria produced stem of 13.0 and 14.7; 12.6 and $13.4 \mathrm{~cm}$ diameter, while those developed naturally, support structures diameters of 11.9 and 13.26; 10.8 and $11.5 \mathrm{~cm}$, respectively.

\section{Root dry matter}

The highest root dry matter was determined in treated IAC91-1099 plants, irrigated at 14- and 21-day intervals, which were 13.7 and $15.0 \mathrm{~g}$, respectively. In addition, $B$. aryabhattai more than doubled the root dry matter yield in plants irrigated at a frequency of 21 days, relative to the control, for this variety.
However, the variety RB85-5156 was not responsive to the presence of the bacteria in its roots, showing no positive effect of the inoculation of the seedlings when transplanted for later development in soil.

\section{Shoot dry matter}

Finally, in relation to shoot dry matter, treated and natural IAC91-1099 plants produced, on average, 43.7 and $34.5 \mathrm{~g}$, respectively. This dissimilarity is consistent because, in addition to inducing root growth, $B$. aryabhattai intensified the accumulation of stem biomass and allowed greater availability of tillers and completely expanded leaves. The benefits of $B$. aryabhattai become even more evident in irrigated plants at intervals of 7 and 14 days, which provided, 52.4 and 61.1 ; 35.9 and $45.7 \mathrm{~g}$, for inoculated and noninoculated plants, respectively. In all the water stressed microenvironments, IAC91-1099 plants obtained higher productive yields of shoot dry matter, compared to those of RB85-5156.

\section{Principal component analysis of vegetative charac- teristics of sugarcane plant varieties and factorial map and fuzzy clusters of water stress environments}

From the analysis of main components, two subsets obtained the maximum variability, statistically useful in relation to the morphological alterations in of the sugarcane plant varieties, IAC91-1099 and RB855156, natural and treated with $B$. aryabhattai, cultivated in environments of water stress imposed by irrigation frequencies (Table 3).

Table 3 - Principal component analysis of vegetative phenotypic traits of the sugarcane varieties, IAC91-1099 and RB85-5156, untreated or treated with $B$. aryabhattai, cultivated in environments of water stress imposed by irrigation frequencies.

\begin{tabular}{lcc}
\hline & Primary component & Secondary component \\
Eigenvalue & $4.48^{*}$ & $1.03^{*}$ \\
Percentage of variance & 74.67 & 13.82 \\
Accumulated percentage of variance & 74.67 & 88.48 \\
\hline & Correlation & \\
Plant height & $0.94^{*}$ & 0.28 \\
Number of tillers & $0.83^{*}$ & -0.42 \\
Number de leaves & $0.82^{*}$ & -0.13 \\
Stem Diameter & $0.72^{*}$ & $0.65^{*}$ \\
Root dry mass & $0.86^{*}$ & 0.37 \\
Shoot dry mass & $0.99^{*}$ & 0.05 \\
\hline & Standard Contribution & \\
Plant height & 0.20 & 0.09 \\
Number of tillers & 0.16 & 0.21 \\
Number de leaves & 0.15 & 0.02 \\
Stem Diameter & 0.12 & 0.50 \\
Root dry mass & 0.16 & 0.16 \\
Shoot dry mass & 0.21 & 0.02 \\
\hline
\end{tabular}

* Significant by the Kaiser-Meyer-Olkin and Pearson tests $(P<0.05)$. 
The degree and direction of correlations between vegetative characteristics, plant height, number of tillers and leaves, stem diameter, dry mass of roots and shoot, and primary subset, describe genotypic responsibility of $B$. aryabhattai to induced tolerance to dryness because this bacterium vigorously promoted this in IAC91-1099 plants. In relation to the secondary subset, correlated to stem diameter, this could be interpreted as phenotypic adaptability to the water restriction, because stressed plants often concentrate energy to the development of organs related to the abstraction and transport of water and nutrients, and to the formation of structures that would intensify evapo- transpiration, such as leaves and tillers in sugarcane cultivation. Despite the insignificance, these characteristics correlate inversely to the secondary subset.

From the factorial map, irrigated plants of IAC91-1099 were grouped as close as possible to the vegetative characteristics, plant height, number of tillers and leaves, dry matter of roots and shoot, while irrigated plants of RB85-5156 were opposed to the morphological indicative for drought-tolerant responsiveness induced by $B$. aryabhattai; however, the stem diameter was a characteristic adapted to draught stress (Figure 2).

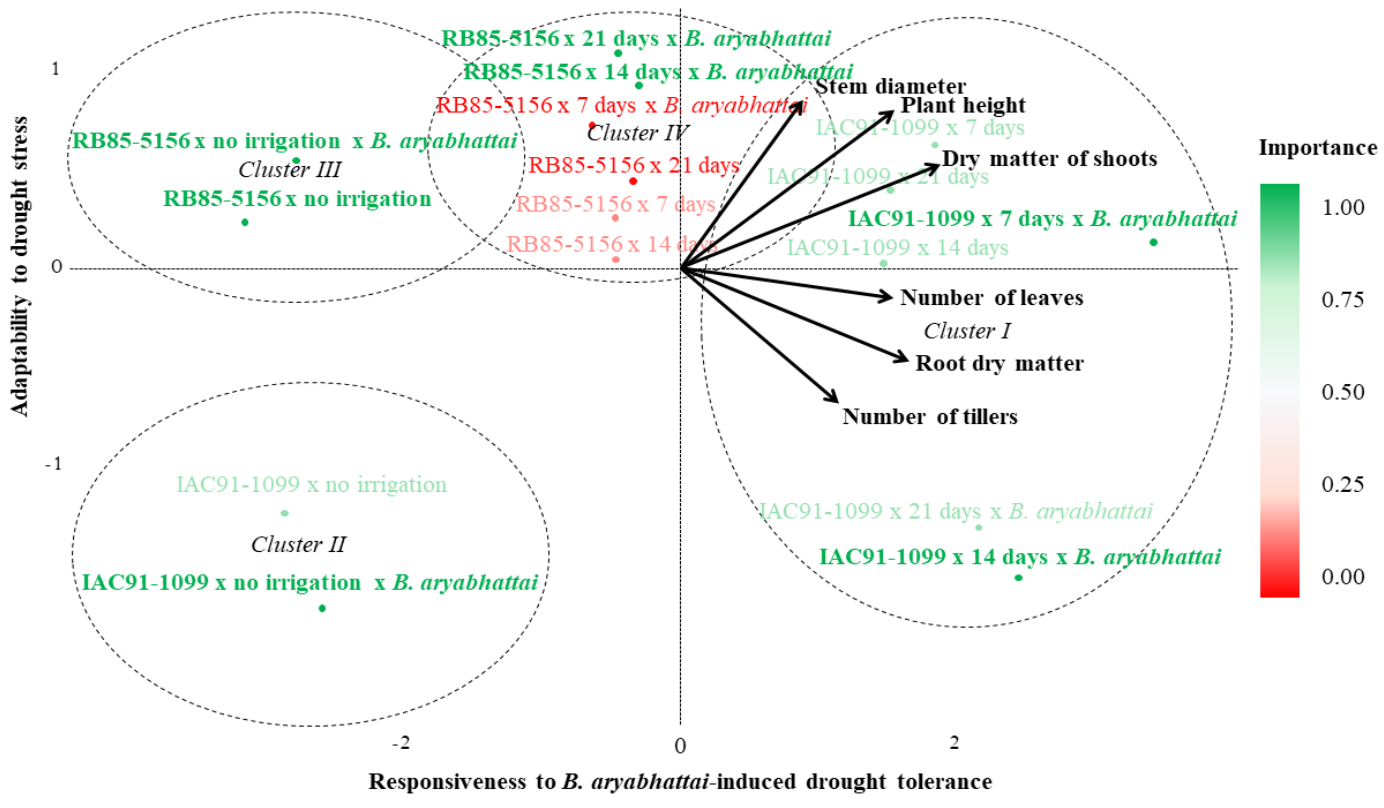

Figure 2 - Factorial map and fuzzy clusters of water stress environments imposed by irrigation frequencies applied to the cultivation of the sugarcane plant varieties, IAC91-1099 and RB85-5156, natural and treated with B. aryabhattai.

The axes $\mathrm{X}$ and $\mathrm{Y}$ associated to fuzzy clusters I, II, III, and IV, identify the main morphological alterations that distinguish plants genetically predisposed to the induction of drought tolerance by $B$. aryabhattai and those indifferent to biological treatment, which are naturally capable of triggering mechanisms that are adaptive to water stress. The sugarcane variety RB855156, which was irresponsive to the bacteria, could channel energy flow to the development of structures that allow the complete efficiency of water use in irrigated systems, instead of directing it to the production of aerial organs that intensified evapotranspiration. In contrast, IAC91-1099, which was synergistic to the bacterial association, could tolerate drought, due to the growth of a root system capable of capturing water and nutrients at considerable soil depths and availability of leaves with greater effective photosynthetic area. In this case, an overdeveloped plant would be the main consequence of the benefits of $B$. aryabhattai for plant height, shoot dry matter, and numbers of tillers and leaves, as illustrated by the fuzzy cluster I.
The fuzzy clusters I, II, and III reflect the inability of $B$. aryabhattai to promote growth in sugarcane plants under environments with marked water stress. Bacterial metabolism is invariably affected by physicochemical properties of soil, mainly acidity, salinity, and water availability.

The dissimilarity between the fuzzy clusters I and II indicate the ability of $B$. aryabhattai to attenuate adversities of water stress in vegetative characteristics of the sugarcane plant variety RB85-5156, which is very sensitive to this abiotic factor.

Finally, the plot of stem diameter, precisely in the intersection zone of the fuzzy clusters I and IV, which contains, respectively, treated and irrigated plants of IAC91-1099 and RB85-5156, reinforces the importance of this characteristic to discern plant materials responsive to the induction of drought tolerance by $B$. aryabhattai and indifferent to inoculation, therefore, necessarily triggering mechanisms that are adaptive to water stress. 


\section{Discussion}

\section{Development of sugarcane plants inoculated with B. aryabhattai}

The sugarcane was influenced by the inoculation of the biological asset in the production phase of the pre-budded seedlings. In relation to the root development of the cultivar IAC 91-1099, B. aryabhattai proved to be an important tool to increase the area of root exploitation in summer situations or absence of water.

Other studied cultures have also been influenced by the presence of microorganisms in their root systems. Mareque et al. (2015) isolated and characterized endophytic bacteria associated with sorghum bicolor (Sorghum bicolor L. Moench), an alternative cereal for the production of bioethanol, forage, silage and grains. Although they did not induce significant changes in stem morphoanatomy, Bacillus spp., Brevibacillus spp., and Paenebacillus spp. considerably influenced root biomass production and plant size. Therefore, this reference corroborates the significant effect of $B$. aryabhattai in relation to root dry mass and plant height.

In plant growth promoting bacteria, siderophores production, indole-acetic acid secretion, and solubilization of inorganic ions are conditioned by microclimate (Solanki et al., 2017). Hence, the natural interaction between irrigation frequency and biological treatment can alter phenotypic characters of the sugarcane seedlings, as observed in this research.

The interaction of the factors, genotype, and biological treatment, in relation to the root dry matter of sugarcane plants, is understandable, as according to Mareque et al. (2015), the synergism between the root system and rhizobacteria is defined, among other possibilities, by the genetic code and microbial predisposition. Tam \& Diep (2014) confirm the occurrence of specificities between genetic accesses of sugarcane to bacterial agents that promote plant growth. From the perspective of the authors, physicochemical properties of rhizosphere and availability of colonizable root niches complete the list of factors that contribute, positively or negatively, to the response of sugarcane to inoculation; our study reiterates the fact.

Regardless of the proposed irrigation management, inoculated plants grew taller, reiterating the benefits of $B$. aryabhattai on the height of sugarcane plant, an agronomic parameter that best represents the vegetative growth induced under water stress (Anjum et al., 2016; Wang et al., 2016). Drought suppresses several characteristics related to plant size; cell division and expansion are the main ones (Anjum et al., 2017). According to these authors, small plants are inefficient in photosynthesis due to the inability to intercept sunlight, a natural resource indispensable for the production of photoassimilates in autotrophic organisms.

The plant exposure to drought causes countless physiological changes detrimental to photosynthesis, such as relief of turgor pressure and foliar senes- cence (Alcázar et al., 2011). The sensitivity of sugarcane to this abiotic factor is determined by the genetic code. In the condition of introduced and natural water deficit, the varieties, RB72-454 and RB85-5536, produce less leaves than SP79-1011, RB86-7515, RB855113, and RB92-579, which present higher loads and provide more tillers per plant (Endres et al., 2018). Under water stress, $B$. subtilis and B. megaterium induce growth in sugarcane cultivation by stimulating the synthesis of acidic invertases, enzymes that hydrolyze sucrose, polysaccharide stored in photosynthetic tissues, and incomplete stem parenchyma. The main consequences of this biochemical reaction are redirection and distribution of monosaccharides in root system tissues, allowing it to grow and then absorb available minerals in soil depths that would usually not be accessed under natural development (Chandra et al., 2018). These previous studies could thus substantiate the identified inequalities in size and density of tillers and leaves of the varieties IAC91-1099 and RB85-5156 and provide clues as to how $B$. aryabhattai could increase the size of sugarcane seedlings by inducing the endogenous production of functional proteins associated with the partition of important organic substrates to root system growth, ensuring better water and nutrient absorption conditions in hydraulically limited soil.

He \& Gao (2009) and Anjum et al. (2011) describe the reduced number of leaves in a plant stressed by drought as an adaptive strategy to maintain cellular hydration, which corroborates with the results observed in this research. Energy investment in the execution of drought resistance mechanisms, reduction of water loss through transpiration, and maintenance of efficient water use compromise growth due to limited fixation of carbon dioxide $\left(\mathrm{CO}_{2}\right)$ by underdeveloped photosynthetic organisms (Khonghintaisong et al., 2018).

Under irrigation periods below 21 days, $B$. aryabhattai provided better conditions for the shoots of both sugarcane varieties to develop radially, probably due to the induction of changes in morphology and availability of xylem vessels, alternatives to relieving water stress (Khonghintaisong et al., 2018). Although not explored in the present research, it is indeed important to underscore that species of Bacillus spp. possess the ability to secrete plant hormones, which may partly explain the enhancement of phenotypic traits found in sugarcane seedlings inoculated with $B$. aryabhattai (Davière \& Archard, 2013; Vurukonda et al., 2016; Arkhipova et al. (2007); Liu et al., 2013). In plants under water stress, stem diameter is retracted due to the inability to maintain cell turgor, affected by the availability of water in soil (Huang et al., 2013; Anjum et al., 2017). Therefore, these references explain the occurrence of smaller diameter stem in sugarcane plants under dry environments and irrigated every 21 days, which are probably stressful, and would precede the probable contribution of $B$. aryabhattai to radial expansion of stem cells by the secretion of phytohormones regulating stem morphology, mainly cytokinins. 
Santos \& Rigobelo (2016) report greater dry matter yield of plant roots, from pre-sprouted seedling, of sugarcane inoculated with $B$. subtilis and $B$. licheniformis. This characteristic is fundamental to the induction of drought tolerance in sugarcane cultivation, since massive roots facilitate the capture of water and nutrients by the extended surface of contact and greater density of root hairs. Interestingly, the biological treatment intensified the accumulation of dry matter in the root system of plants under water-limited conditions, proving the ability of $B$. aryabhattai to alter it, morphoanatomically. Kruasuwan \& Thamchaipenet (2016) emphasize that sugarcane plants inoculated with the bacteria, Streptomyces spp., Enterobacter spp. and Bacillus spp., produce more dry matter of roots and shoots. The authors attributed part of the success of biological treatments to the effectiveness of microbial solubilization of inorganic phosphates, energy resources that provide nutritional balance to the plant. In an environment with water deficit, the sugarcane crop can also grow a massive and deep root system, probably as an adaptive response to the restricted availability of water in superficial soil layers (Khonghintaisong et al., 2018). These observations may help explain the nonlinear trends regressed to the interactive effect of frequency of irrigation and biological treatment, in relation to root dry matter production in both varieties of sugarcane studied.

The frequency of irrigation, genotype, and biological treatment influenced plant height, number of leaves, stem diameter, and root dry mass, interactively; these vegetative characteristics influence the shoot dry matter yield. In plants stressed by drought, the inexpressive production of shoot dry matter is due to the inefficient absorption and xylem translocation of water and nutrients (Jangpromma et al., 2012). Similarly, Selvakumar et al. (2012) associate biomass unproductivity with the nutritional imbalance caused by water stress. Water deficit in sugarcane cultivation causes unproductivity of shoot dry matter, due to the underdevelopment of support structures and leaves, which are essential organs for the photosynthetic efficiency (Vurukonda et al., 2016; Khonghintaisong et al., 2018). Therefore, B. aryabhattai inoculated sugarcane seedlings may improve shoot dry matter in varieties IAC911099 and RB85-5156 and, consequently, ensuring better yields than biologically untreated seedling when grown in soils with low hydric resource.

\section{Morphological indicators of induced drought tolerance and morphological adaptability to water stress}

According to the literature, most of the adaptation mechanisms by plants to water deficit occur in photosynthetic organisms, while alteration of root system architecture, increased size, and overproduction of effective leaves represent the main morphological indications of water stress tolerance in cultures treated with growth promoting bacteria, including those belonging to the genus Bacillus spp. In this research, according to the contribution analysis, the responsive- ness of sugarcane genotypes, mainly IAC91-1099, to the induction of drought tolerance by $B$. aryabhattai application is best evidenced by the higher shoot dry matter yield, followed by increases in plant height, root dry matter accumulation and number of tillers, number of leaves, and stem diameter. In relation to the adaptability to water stress, this would be better characterized by the radial expansion of stem, limited production of smaller leaves and slight increase in dry matter production (Table 3).

The water deficit causes a complete failure of functions crucial to the synthesis of phytohormones and siderophores, biological fixation of atmospheric N2, and solubilization of nutrients (Vurukonda et al., 2016). Therefore, this could explain, in addition to the similarity between vegetative characteristics of untreated and treated plants cultivated in unirrigated environments, the relative water dependence of $B$. aryabhattai, as evidenced by the graphical representations of IAC91-1099 plants grown under irrigation frequencies of 7 and 14 days (Figure 2). The dissimilarity between fuzzy clusters I and II (Figure 2) corroborate the ability of $B$. aryabhattai to attenuate water stress adversities in vegetative characteristics of the sugarcane plant variety RB85-5156, which is very sensitive to this abiotic factor.

In short, the visualization of this factorial map facilitates our interpretation of the interactions found for genotype, biological treatment, and water stress levels, revealing the main cause-effect factors involved in the studied system.

\section{Conclusion}

The osmotolerant microorganism, $B$. aryabhattai, is technically an effective biological asset for priming sugarcane plants to better withstand water stress and, therefore, qualifies as a low-cost alternative to establish sugarcane plantations in marginal lands, in which pluviometric regimes are limiting factors to the planning and expansion of the sugar-energy sector in Brazil.

\section{References}

Agroanalysis E (2017) Reavaliação da safra 2016/17 e primeira visão da safra 2017/18. AgroANALYSIS 36:36- 40.

Alcázar R, Bitrián M, Bartels D, Koncz C, Altabella T, Tiburcio AF (2011) Polyamine metabolic canalization in response to drought stress in Arabidopsis and the resurrection plant Craterostigma plantagineum. Plant Signaling \& Behavior 6:243 - 250. doi:10.4161/psb.6.2.14317

Anjum SA, Ashraf U, Zohaib A, Tanveer M, Naeem M, Ali I, Tabassum U, Nazir U (2017) Growth and development responses of crop plants under drought stress: a review. Zemdirbyste-Agriculture 104:267 - 276. doi:10.13080/z-a.2017.104.034 
Anjum SA, Ran W, Jian-Hang N, Zohaib A, Jin-Huan L, Mei-Ru L, Ji-xuan S, Jun LV, San-Gen W, Xue-Feng Z (2016) Exogenous application of ALA regulates growth and physiological characters of Leymus chinensis (Trin.) Tzvel. under low temperature stress. Journal of Animal \& Plant Sciences 26:1354-1360.

Anjum SA, Xie XY, Wang LC, Saleem MF, Man C, Lei W (2011) Morphological, physiological and biochemical responses of plants to drought stress. African Journal of Agricultural Research 6:2026 - 2032. doi: 10.5897/AJAR10.027

Arkhipova TN, Prinsen E, Veselov SU, Martinenko EV, Melentiev Al, Kudoyarova GR (2007) Cytokinin producing bacteria enhance plant growth in drying soil. Plant and Soil 292:305 - 315. doi: $10.1007 /$ s $11104-007-9233-5$

Chandra P, Tripath, P, Chandra A (2018) Isolation and molecular characterization of plant growth-promoting Bacillus spp. and their impact on sugarcane (Saccharum spp. hybrids) growth and tolerance towards drought stress. Acta Physiologiae Plantarum. 40:199 - 214. doi: 10.1007/s11738-018-2770-0

Cherif $H$, Marasco R., Rolli E, Ferjani R, Fusi M, Soussi A, Mapelli F, Blilou I, Borin S, Boudabous A, Cherif A, Daffonchio D, Ouzari H (2015) Oasis desert farming selects environment-specific date palm root endophytic communities and cultivable bacteria that promote resistance to drought. Environmental Microbiology Reports. 7:668 - 678. doi: 10.1111/17582229.12304

Conab - Companhia Nacional de Abastecimento (2018) Acompanhamento da safra brasileira: Cana de açúcar safra 2018/2019. https://www.conab.gov.br/info-agro/safras/cana (Acessado em 15 de Dezembro de 2018).

Davière J, Achard P (2013) Gibberellin signaling in plants. Development. 140:1147 - 1151. doi: 10.1242/dev.087650

Endres L, Santos CM, Souza GV, Menossi M, Santos JCM (2018) Morphological changes recorded in different phenophases of sugarcane plants subjected to water stress in tropical field conditions. Australian Journal of Crop Science 12:1041 - 1050.

Huang C, Zhao S, Wang L, Anjum SA, Chen M, Zhou $\mathrm{H}$, Zou C (2013) Alteration in chlorophyll fluorescence, lipid peroxidation and antioxidant enzymes activities in hybrid ramie (Boehmeria nivea L.) under drought stress. Australian Journal of Crop Science 7:594 - 599.

Jangpromma $N$, Thammasirirak $S$, Jaisil $P$, Songsri $P$ (2012) Effects of drought and recovery from drought stress on above ground and root growth, and water use efficiency in sugarcane (Saccharum officinarum L.). Australian Journal of Crop Science 6:1298 - 1304.
Jolliffe IT, Cadima J (2016) Principal component analysis: a review and recent developments. Philosophical Transaction of the Royal Society A 374:1 - 16. doi: 10.1098/rsta.2015.0202

Kavamura V, Santos SN, Silva JL, Parma MM, Avila LA, Visconti A, Zucchi TD, Taketani RG, Andreote FD, Melo IS (2013) Screening of Brazilian cacti rhizobacteria for plant growth promotion under drought. Microbiological Research, 168:183 - 191. doi: 10.1016/j.micres.2012.12.002

Khonghintaisong J, Songsri $P$, Toomsan B, Jongrungklang $N$ (2018) Rooting and physiological trait responses to early drought stress of sugarcane cultivars. Sugar Technology 20:396 - 406. doi: 10.1007/s12355-017-0564-0

Kruasuwan W, Thamchaipenet A (2016) Diversity of culturable plant growth-promoting bacterial endophytes associated with sugarcane roots and their effect of growth by co-inoculation of diazotrophs and actinomycetes. Journal of Plant Growth Regulation, 35: 1074 - 1087. doi: 10.1007/s00344-016-9604-3

Landell MGA, Campana MP, Figueiredo P (2012) Sistema de multiplicação de cana-de-açúcar com uso de mudas pré-brotadas (MPB), oriundas de gemas individualizadas. Campinas: Instituto Agronômico, 109: 16.

Liu F, Xing S, Ma H, Du Z, Ma B (2013) Cytokinin-producing, plant growth-promoting rhizobacteria that confer resistance to drought stress in Platycladus orientalis container seedlings. Applied Microbiology and Biotechnology, 97: 9155 - 9164. doi: 10.1007/s00253-0135193-2

Mapa - Ministério da Agricultura, Pecuária e Abastecimento/ Secretaria de Produção e Agroenergia (2017) Tabela de Comparação da Produção Sucroalcooleira no Brasil. http://www.agricultura.gov.br/assuntos/sustentabilidade /agroenergia/producao (Acessado em 15 de Dezembro de 2018)

Mareque C, Taulé C, Beracochea M, Battistoni $F$ (2015) Isolation, characterization and plant growth promotion effects of putative bacterial endophytes associated with sweet sorghum (Sorghum bicolor (L) Moench). Annals of Microbiology, 65: 1057 - 1067. doi: 10.1007/s13213-014-0951-7

Naser V, Shani E (2016) Auxin response under osmotic stress. Plant Molecular Biology, 91: 661 - 672. doi: 10.1007/s11103-016-0476-5

Nayak, J, Naik, B, Behera, HS (2015) Fuzzy c-means (FCM) clustering algorithm: a decade review from 2000 to 2014. In: Jain L., Behera H., Mandal J., Mohapatra D. (Eds.), Computational intelligence in data miningvolume 2. Springer, New Delhi, pp. 133 - 159. 
Park YG, Mun BG, Kang SM, Hussain A, Shahzad R, Seo CW, Kim AY, Lee SU, Oh KY, Lee DY, Lee IJ, Yun BW (2017) Bacillus aryabhattai SRB02 tolerates oxidative and nitrosative stress and promotes the growth of soybean by modulating the production of phytohormones. PloS One, 12, e0173203. doi: 10.1371/journal.pone.0173203

R Core Team (2017) R: A Language and Environment for Statistical Computing. R Foundation for Statistical Computing, Vienna, Austria. URL https://www.Rproject.org/, 2017.

Santos MS, Stancatte RS, Ferreira TC, Dorighello DV, Pazzianotto RAA, Melo IS, May A, Ramos NP (2017) Resistance to water deficit during the formation of sugarcane seedlings mediated by interaction with Bacillus sp. Científica, 45:414-421. doi: 10.15361/19845529.2017v45n4p414-421

Santos RM, Rigobelo EC (2016) Uso de Bacillus subtilis e Bacillus licheniformis na promoção de crescimento de mudas pré-brotadas de cana-de-açúcar. Ciência e Tecnologia: FATEC-JB, 8: 1 - 5 .

Schmidt R, Köberl M, Mostafa A, Ramadan EM, Monschein M, Jensen KB, Bauer R, Berg G (2014) Effects of bacterial inoculants on the indigenous microbiome and secondary metabolites of chamomile plants. Frontiers in Microbiology, 5: 1 - 10. doi: 10.3389/fmicb.2014.00064

Selvakumar G, Panneerselvam P, Ganeshamurthy AN (2012) Bacterial mediated alleviation of abiotic stress in crops. In: Maheshwari D. (Eds.), Bacteria in Agrobiology: Stress Management. Springer, Berlin, pp.205$-224$.
Siddikee MA, Chauhan PS, Anandham R, Han GH, Sa $\mathrm{T}$ (2010) Isolation, characterization, and use for plant growth promotion under salt stress, of ACC deaminase-producing halotolerant bacteria derived from coastal soil. Journal of Microbiology and Biotechnology, 20: 1577 - 1584.

Solanki, MK, Wang Z, Wang FY, Li CN, Lan TJ, Singh RK, Singh P, Yang LT, Li YR (2017) Intercropping in sugarcane cultivation influenced the soil properties and enhanced the diversity of vital diazotrophic bacteria. Sugar Tech, 19: 136 - 147. doi: 10.1007/s12355016-0445-y

Tam HM, Diep CN (2014) Isolation, characterization and identification of endophytic bacteria in sugarcane (Saccharum spp. L.) cultivated on soils of the Dong Nai province, Southeast of Vietnam. American Journal of Life Sciences, 2: 361 - 368. doi: 10.11648/j.ajls.20140206.16

Vurukonda SSKP, Vardharajula S, Shrivastava M, SkZ A (2016) Enhancement of drought stress tolerance in crops by plant growth promoting rhizobacteria. Microbiological Research, 184: 13 - 24. doi: 10.1016/j.micres.2015.12.003

Wang R, Anjum SA, Niu J, Liu M, Li J, Zohaib A, Zong $X$ (2016) Exogenous application of brassinolide ameliorate chilling stress in Leymus chinensis (Trin.) Tzvel. by modulating morphological, physiological and biochemical traits. Bangladesh Journal of Botany, 45:143-150. 